\title{
Dinitroaniline Herbicide Resistance and Mechanisms in Weeds
}

\author{
Jinyi Chen ${ }^{1,2}$, Qin Yu ${ }^{1 *}$, Eric Patterson ${ }^{2}$, Chad Sayer $^{3}$ and Stephen Powles ${ }^{1}$ \\ ${ }^{1}$ Australian Herbicide Resistance Initiative (AHRI), School of Agriculture and Environment, University of Western Australia \\ (UWA), Perth, WA, Australia, ${ }^{2}$ Department of Plant, Soil, and Microbial Sciences, Michigan State University, East Lansing, \\ MI, United States, ${ }^{3}$ Nufarm Limited, Melbourne, VIC, Australia
}

\section{OPEN ACCESS}

Edited by:

Joel Torra,

Universitat de Lleida, Spain

Reviewed by:

Rafael De Prado,

University of Córdoba, Spain

Marcos Yanniccari,

Consejo Nacional de Investigaciones Cientificas y Técnicas (CONICET),

Argentina

*Correspondence:

Qin Yu

qin.yu@uwa.edu.au

Specialty section:

This article was submitted to Crop and Product Physiology,

a section of the journal

Frontiers in Plant Science

Received: 27 November 2020

Accepted: 08 March 2021

Published: 25 March 2021

Citation:

Chen J, Yu Q, Patterson E,

Sayer $C$ and Powles $S$ (2021) Dinitroaniline Herbicide Resistance

and Mechanisms in Weeds.

Front. Plant Sci. 12:634018.

doi: 10.3389/fpls.2021.634018
Dinitroanilines are microtubule inhibitors, targeting tubulin proteins in plants and protists. Dinitroaniline herbicides, such as trifluralin, pendimethalin and oryzalin, have been used as pre-emergence herbicides for weed control for decades. With widespread resistance to post-emergence herbicides in weeds, the use of pre-emergence herbicides such as dinitroanilines has increased, in part, due to relatively slow evolution of resistance in weeds to these herbicides. Target-site resistance (TSR) to dinitroaniline herbicides due to point mutations in $\alpha$-tubulin genes has been confirmed in a few weedy plant species (e.g., Eleusine indica, Setaria viridis, and recently in Lolium rigidum). Of particular interest is the resistance mutation Arg-243-Met identified from dinitroaniline-resistant L. rigidum that causes helical growth when plants are homozygous for the mutation. The recessive nature of the TSR, plus possible fitness cost for some resistance mutations, likely slows resistance evolution. Furthermore, non-target-site resistance (NTSR) to dinitroanilines has been rarely reported and only confirmed in Lolium rigidum due to enhanced herbicide metabolism (metabolic resistance). A cytochrome P450 gene (CYP81A10) has been recently identified in $L$. rigidum that confers resistance to trifluralin. Moreover, TSR and NTSR have been shown to co-exist in the same weedy species, population, and plant. The implication of knowledge and information on TSR and NTSR in management of dinitroaniline resistance is discussed.

Keywords: dinitroaniline herbicides, trifluralin (herbicide), target-site resistance, tubulin mutations, non-targetsite resistance, metabolic resistance

\section{INTRODUCTION}

Weeds are a major threat to global food security. Weeds cause tremendous economic loss to agriculture by competing with crops for light, nutrition and water, and decreasing crop yield (Oerke, 2006). Herbicides are vital tools in controlling weeds, saving both time and labor, which in turn contributes immensely to global food production (Shaner, 2014). The first synthetic herbicide, 2,4-D, was produced in 1941 by Robert Pokorny and it is still being used today for broad-leaf weed control (Stephenson et al., 2001). After its discovery, new herbicide "modes of action" have been introduced approximately every 3 years, leading to the current availability of about 20 known modes of action.

However, persistent global herbicide application on large weed populations has resulted in the evolution of herbicide resistant weed populations. Since the first well documented herbicide resistant case for triazines in 1970 (Ryan, 1970), the total number of herbicide-resistant weed 
species has increased dramatically. A conservative estimate shows herbicide resistance has evolved in 262 weed species across 71 countries (Heap, 2021). What is worse, the number of herbicide resistant weed is still increasing, whereas development of new modes of action herbicides has been decreasing since 1991 (Duke, 2012).

With ever increasing herbicide resistance, understanding resistance mechanisms provides scientists and agronomists a theoretical framework to better control, mitigate, and manage herbicide resistant populations. This review focuses on the dinitroaniline herbicides and encompasses 1) the development of dinitroaniline herbicides, 2) resistance evolution and mechanisms, 3) inheritance, 4) potential fitness cost and 5) discussions on possible tactics to mitigate dinitroaniline resistance evolution.

\section{DEVELOPMENT OF DINITROANILINE HERBICIDES}

Dinitroanilines represent a class of chemicals with a structure containing two nitro groups and an aromatic amine, aniline. Originally discovered in evaluations of dyes and dye chemical synthesis intermediates, dinitroanilines grew to be widely used in agriculture, industry and medical science (Dekker, 1999). In agriculture, dinitroanilines are mainly used as preemergence herbicides to control grass and some broadleaf weeds (Parka and Soper, 1977). The commercialized dinitroaniline herbicides so far include trifluralin, pendimethalin, ethalfluralin, oryzalin, butralin, benefin/benfluralin and prodiamine. The first dinitroaniline herbicide, trifluralin ( $\alpha, \alpha, \alpha$-trifluoro-2,6-dinitro$N, N$-dipropyl-p-toluidine, Figure 1), was commercialized in the 1960s in the United States (Grover et al., 1997; Timmons, 2005). Originally it was used in soybean fields by pre-plant soil-incorporation for grass weed control (Epp et al., 2017). Later on, trifluralin was introduced into Latin America and Asia Pacific and extensively used in sugarcane and soybean in Brazil (Lima et al., 2018), and Australian cereal and legume fields (Jolley and Johnstone, 1994). With the introduction of newly developed, highly efficient postemergence ALS- and ACCase-inhibitors in 1980s, trifluralin usage declined and the trifluralin market was significantly replaced by these newer herbicides. However, due to the rapid resistance evolution to these newer, post-emergence herbicides and the adoption of no-till or reduced tillage techniques for soil and moisture conservation, trifluralin

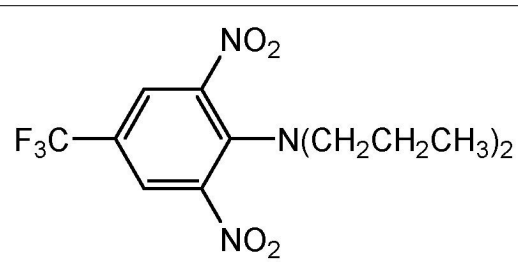

FIGURE 1 | Trifluralin chemical structure. has resurged in many markets. According to data from the Brazilian Institute of Environment and Renewable Natural Resources, sales of trifluralin comprised 1,887 tons in 2019 (Instituto Brasileiro do Meio Ambiente e dos Recursos Naturais Renováveis (IBAMA), 2020). In the United States, trifluralin was among the 25 most used pesticides in agriculture, and the estimated usage ranged from 1361 to 3175 tons in 2012 [Environmental Protection Agency (EPA), 2021]. In recent years trifluralin and pendimethalin have been the two most significant dinitroaniline herbicides used, estimated to represent a global farm gate value (the dollar amount of sales of product made to the actual farmer) of \$USD 525 million. When considering trifluralin/pendimethalin, over $30 \%$ of the farm gate value is within the Australian and North American markets, and $50 \%$ of farm gate value is in cereals, cotton, vegetables and soybean. Controlling weed populations resistant to other herbicide chemistries is generally accepted as a significant factor driving dinitroaniline herbicide use in these regions and crops.

\section{BEHAVIOR AND MODE OF ACTION OF DINITROANILINE HERBICIDES}

Dinitroanilines have low water solubility $\left(20^{\circ} \mathrm{C}\right.$ in water, $0.22 \mathrm{mg} / \mathrm{L}$ for trifluralin, and $0.33 \mathrm{mg} / \mathrm{L}$ for pendimethalin). According to Environmental Protection Agency (EPA) 1996, trifluralin ranks as moderate to highly toxic for aquatic animals (fish and invertebrates) [Environmental Protection Agency (EPA), 1996]. Most dinitroaniline herbicides are highly volatile. At $25^{\circ} \mathrm{C}$, the volatility of trifluralin is $9500 \mathrm{kPa}$, and pendimethalin, $1940 \mathrm{kPa}$ (versus $3.17 \mathrm{kPa}$ for water) (Congreve and Cameron, 2014). Dinitroanilines are subject to decomposition due to photodegradation (Wright and Warren, 1965), and its effectiveness is greatly affected by its soil incorporation depth (Savage and Barrentine, 1969; Spencer and Cliath, 1974). Therefore, dinitroaniline herbicides need to be incorporated with surface soil to minimize volatilization and photodegradation loss. Particularly, in Australia, the "incorporate by sowing" technique uses a knife point seeder to throw soil into the inter-row to cover the herbicide and reduce loss due to volatilization (Ashworth et al., 2010). When within the soil, dinitroanilines have strong binding coefficient $\left(\mathrm{K}_{\mathrm{oc}}\right.$, if $\mathrm{K}_{\mathrm{oc}}>4,000$, non-mobile) with the soil $\left(\mathrm{K}_{\mathrm{oc}}\right.$ pendimethalin $=17,581, \mathrm{~K}_{\mathrm{oc}}$ trifluralin $\left.=15,800\right)($ Helling, 1971, 1976; Congreve and Cameron, 2014), and slow microbial degradation. Microbial degradation is the primary breakdown route; however, persistence is generally long, often resulting in rotational crop limitations (Congreve and Cameron, 2014).

Due to low solubility in soil moisture and strong soil-binding, dinitroanilines enter the germinating seedlings primarily via gaseous absorption through the root, coleoptile node or hypocotyl, upon contact with the herbicide (Congreve and Cameron, 2014). Trifluralin soil-borne vapor plays an important phytotoxic role especially to plant roots (Barrentine and Warren, 1971; Charles and Richard, 1972). In early research on dinitroaniline herbicides uptake and 


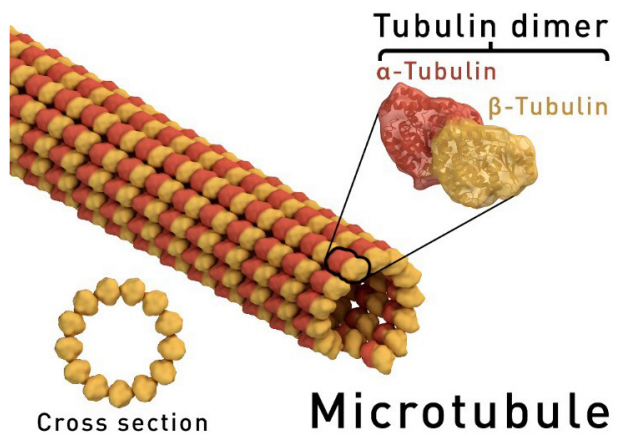

FIGURE 2 | Simulative structure of a microtubule. The ring shape depicts a microtubule in cross-section, showing the 13 protofilaments surrounding a hollow centre (https://goo.gl/images/BKJ9m3, under the Creative Commons Attribution-Share Alike 4.0 International license).

translocation, it was found that in both monocots and dicots, the translocation of ${ }^{14} \mathrm{C}$-profluralin radioactivity to plant tops was very limited, while ${ }^{14} \mathrm{C}$-dinitramine was more readily translocated throughout the plant, and higher temperature $\left(38^{\circ} \mathrm{C}\right.$ ) could help enhance the translocation to leaves (Hawxby, 1974). Limited trifluralin translocation to the aerial portions of the plant was reported in soybean and cotton plants (Strang and Rogers, 1971), and in Alopecurus aequalis seedlings (Hashim et al., 2012).

Dinitroanilines target microtubules, which, together with microfilaments and intermediate filaments, are major components of the cytoskeleton. Microtubules are hollow cylinders, about $25 \mathrm{~nm}$ in diameter, that are comprised of $\alpha$ - and $\beta$-tubulin heterodimers (usually 13 protofilaments in eukaryotic cells) (Figure 2; Tilney et al., 1973; Desai and Mitchison, 1997; Downing and Nogales, 1998a,b). The $\alpha$ - and $\beta$-tubulins, each with a molecular weight of 50,000 daltons, share $36-42 \%$ amino acid sequence identity (Little and Seehaus, 1988). Microtubules perform various functions at different stages of cellular activity. During interphase, microtubules are critical for orchestrating cell wall synthesis in plant cells. Also, microtubules are anchored to the plasma membrane, forming cortical microtubules to help support cell shape. During mitosis, the bipolar spindle apparatus is comprised of microtubules and is capable of correctly positioning chromosomes to the cell midplane and then guiding separated chromatids to opposite ends of the cell (Shaw and Vineyard, 2014). To realize their mobile function(s), microtubules are required to be in a dynamic balance. There is a positive $(+)$ and negative $(-)$ end for microtubules; the positive end assembles the heterodimers using GTP, while the negative end dissociates into heterodimers. With balanced polymerization and de-polymerization, mitosis proceeds normally.

Dinitroanilines disrupt microtubule function by binding with unpolymerized tubulin heterodimers. In vitro analyses of Chlamydomonas reinhardtii tubulin showed specific binding with trifluralin, indicating that tubulin is the primary subcellular target of dinitroaniline action (Stokkermans et al., 1996). Similar for tubulin from Zea mays L., dinitroanilines bind to the unliganded $\alpha / \beta$-tubulin heterodimers to form a herbicidetubulin complex, and, with addition of the complex to the positive end of the growing microtubule, further elongation of the microtubule ceases (Hugdahl and Morejohn, 1993). Concomitantly, due to depolymerization of microtubules from the negative end, the microtubules become progressively shorter, eventually leading to their complete dissociation (Cleary and Hardham, 1988). When this occurs, mitosis is disturbed and mitotic cells are arrested in telophase. This is also supported by the cytological studies showing arrested mitosis at prometaphase due to loss of spindle microtubules, and formation of isodiametric cells in the elongation zone due to loss of cortical microtubules after trifluralin treatment (Vaughn, 1986). The cessation of cell division causes treated seedlings to exhibit swollen and stunted root symptoms (Lignowski and Scott, 1971). The affected seedlings either cannot emerge from the soil or there is no growth after emergence.

Interestingly, dinitroaniline herbicides target microtubules from both plants and protists, but not from animals or fungi (Chan and Fong, 1994; Bell, 1998; Dempsey et al., 2013), likely due to differences in binding affinities for animal tubulins. Oryzalin was found to bind in vitro to tubulins isolated from maize and Chlamydomonas eugametos, but not to purified tubulins from bovine brain tissue (Strachan and Hess, 1983; Morejohn et al., 1987; Hugdahl and Morejohn, 1993). Carrot is a notable exception and shows natural tolerance to dinitroaniline herbicides. Immunofluorescence and electron microscopy indicated that the microtubules of carrot roots were unaffected by dinitroaniline treatment (Vaughan and Vaughn, 1988).

Dinitroaniline herbicides inhibit the plant tubulin protein family, which is encoded by a multi-gene family comprised of several $\alpha$ - and $\beta$-tubulin genes. In the model plant Arabidopsis thaliana, there are at least six expressed $\alpha$-tubulin genes and nine expressed $\beta$-tubulin genes (Snustad et al., 1992; Kopczak et al., 1992). In rice, there are three $\alpha$-tubulin transcripts and eight $\beta$-tubulin genes reported (Qin et al., 1997; Yoshikawa et al., 2003). Similarly in E. indica, four $\beta$-tubulin and three $\alpha$-tubulin isoforms have been identified (Waldin et al., 1992; Yamamoto et al., 1998; Yamamoto and Baird, 1999), whereas in Setaria viridis, two $\alpha$ and two $\beta$-tubulin genes have been isolated (Waldin et al., 1992; Délye et al., 2004). In cross-pollinated L. rigidum, there are at least four $\alpha$-tubulin isoforms, TUA1, TUA2, TUA3, and TUA4, but the number of transcripts coding for each isoform varies among individual/population (Chen et al., 2020b).

Crop selectivity of dinitroaniline herbicides is possible using physical herbicide positioning between crop and weed seeds in the soil. Crop seeds are beneath the layer of soil containing the dinitroaniline herbicide while the smaller annual weed seeds germinate on or near the soil surface. Furthermore, the trifluralin molecule has some species-specific selectivity and is generally more toxic to grass species (wheat, oats, barley, and rice) than broadleaf species (cotton, soybean, pea, and cucumber) (Barrentine and Warren, 1971). As trifluralin can be trapped in lipids, it is hypothesized that selective phytotoxicity of trifluralin in young seedlings is determined, 
in part, by the amount of endogenous lipids available to trap trifluralin and keep it from its site of phytotoxic action (Hilton and Christiansen, 1972).

\section{RESISTANCE EVOLUTION TO DINITROANILINE HERBICIDES}

Dinitroaniline herbicides have been used for more than 50 years; however, limited cases have been documented for dinitroaniline herbicide resistance in weedy species. Globally, thus far, populations of only seven weed species have been identified to be resistant to dinitroaniline herbicides (Heap, 2021): E. indica, S. viridis, Amaranthus palmeri, Alopecurus myosuroides, Lolium rigidum, Poa annua and Alopecurus aequalis. These resistant weed populations are mostly in Australia, America, and Japan, where dinitroaniline herbicides have been intensively used.

E. indica from South Carolina was among the first reports of dinitroaniline resistance following about a decade's persistent application (Mudge et al., 1984). Subsequently, two more dinitroaniline-resistant biotypes of $E$. indica (i.e., resistant and intermediate resistant) were characterized (Vaughn et al., 1990). Later resistance was found in populations of A. palmeri and P. annua from other parts of the Carolinas and Georgia (Gossett et al., 1992; Lowe et al., 2001; Isgrigg et al., 2002).

Setaria viridis is the major dinitroaniline-resistant weed species reported in Canada. Trifluralin-resistant S. viridis populations were first found in southern and southwestern Manitoba (Morrison et al., 1989), and the resistance persisted for at least 7 years (Andrews and Morrison, 1997). In United Kingdom, one chlorotoluron-resistant A. myosuroides population was reported to metabolize and thus resist pendimethalin but not trifluralin (James et al., 1995). In Japan, trifluralin-resistant $A$. aequalis populations were identified after more than two decades of dinitroaniline usage (Hashim et al., 2012).

Lolium rigidum from Australia is prone to herbicide resistance evolution, and dinitroaniline herbicides are no exception (McAlister et al., 1995). Periodic herbicide resistance surveys in Australian agricultural areas show that more than $50 \%$ surveyed populations from South Australia and Victoria, and 26\% from the Western Australia have become trifluralin resistant (Boutsalis et al., 2006; Owen et al., 2007, 2014). Among others, this is likely ascribed to reduced herbicide control efficacy due to high $L$. rigidum seed numbers, low herbicide doses (caused by dry environments, microbial metabolism of the herbicides etc.), and perhaps more importantly, development of metabolism-based cross-resistance in L. rigidum populations selected by other herbicides (e.g., Han et al., 2020). With increasing usage of trifluralin, more trifluralinresistant $L$. rigidum populations are expected.

Relatively slow evolution of dinitroaniline herbicide resistance in weeds is likely due to several reasons: (1) Plants surviving the pre-emergence herbicide treatment early in the season can still be controlled by the application of herbicides from different modes of action, applied post-emergent, as well as by any other control methods implemented; (2) Use mixtures of pre-emergence herbicides with different modes of action significantly improves weed control efficacy (Soltani et al., 2020); and (3) Other factors like the existence of multiple target isoforms, genetic control mechanisms, and fitness costs associated with resistance alleles, as discussed below.

\section{RESISTANCE MECHANISMS TO DINITROANILINE HERBICIDES}

Generally, herbicide resistance mechanisms can be divided into target-site resistance (TSR) and non-target-site resistance (NTSR). TSR refers to resistance caused by the changes in herbicide target protein including mutation, duplication and overexpression, while NTSR includes all resistance mechanisms bypassing the TSR, primarily anything that reduces the amount of herbicide reaching the target protein such as alterations in absorption, translocation or metabolism (Powles and $\mathrm{Yu}, 2010)$. TSR is relatively easy and straightforward to study when the target protein is not part of a multi gene family and in diploid plant species, whereas unraveling NTSR mechanisms is more technically challenging and requires a more in depth understanding of the weed's genetics and physiology.

\section{TSR Mechanisms to Dinitroaniline Herbicides}

Dinitroanilines mainly target $\alpha$ - and $\beta$-tubulin in protists and higher plants. Resistance mutations identified in protists offer valuable reference. In protists, the first $\alpha$-tubulin mutation (Tyr24-His) conferring resistance to dinitroanilines was identified in a single-celled algae: Chlamydomonas reinhardtii (James et al., 1993). Later, more resistance mutations were documented in Toxoplasma gondii (Morrissette et al., 2004; Ma et al., 2007, 2008; Lyons-Abbott et al., 2010) and Tetrahymena thermophila (LyonsAbbott et al., 2010). In weedy plants, the first resistance-endowing tubulin mutation (Thr-239-Ile) was characterized in E. indica (Anthony et al., 1998; Yamamoto et al., 1998). Subsequently, the same mutation was also identified in the protist $T$. gondi (Morrissette et al., 2004) and in weedy species S. viridis (Délye et al., 2004) and more recently in L. rigidum (Chen et al., 2018b). There are other resistance mutations identified in other plants (Table 1) and some of them are shared by plants and protists (Table 2). Thus far, there is a greater number of resistance mutations identified in protists than in plants (Morrissette et al., 2004; Pham and Morrissette, 2019), which may be due to their shorter life cycles, simple genome composition and laboratorybased forced selection/evolution in protists. Given the equal sensitivity to dinitroaniline herbicides in protists and in plants, more resistance-endowing mutations discovered in protists are expected to be eventually detected in plants, as dinitroaniline selection pressure continues and/or increases.

Target-site resistance in the obligatory cross-pollinated L. rigidum is more complicated when compared with selfpollinated weed species, mostly due to Lolium genetic diversity. At least four $\alpha$-tubulin isoforms (named TUA1-TUA4) have been identified in plants from two L. rigidum populations, 
TABLE 1 | Mutations in $\alpha$ - and $\beta$-tubulin identified in field-evolved dinitroaniline-resistant plants.

\begin{tabular}{|c|c|c|c|c|}
\hline Mutation Site & Organism & $\begin{array}{l}\text { Wild type } \\
\text { amino acid }\end{array}$ & $\begin{array}{l}\text { Substituted } \\
\text { amino acid }\end{array}$ & References \\
\hline \multicolumn{5}{|l|}{$\alpha$-tubulin } \\
\hline 125 & A. aequalis & Leu & Met & Hashim et al., 2012 \\
\hline 136 & A. aequalis S. viridis & Leu & Phe & Délye et al., 2004 \\
\hline 202 & A. aequalis L. rigidum & Val & Phe & Hashim et al., 2012; Fleet et al., 2017; Chen et al., 2018b \\
\hline 239 & E. indica S. viridis L. rigidum & Thr & \|le & $\begin{array}{l}\text { Anthony et al., 1998; Délye et al., 2004; Yamamoto et al., } \\
\text { 1998; Fleet et al., 2017; Chen et al., 2018b }\end{array}$ \\
\hline 243 & L. rigidum & Arg & Met/Lys & Chu et al., 2018 \\
\hline 268 & E. indica & Met & Thr & Yamamoto et al., 1998 \\
\hline $390+442^{*}$ & L. rigidum & Arg, Asp & Cys, Glu & Chen et al., 2020b \\
\hline \multicolumn{5}{|l|}{$\beta$-tubulin } \\
\hline 241 & Poa annual $L$. & Arg & Lys & Lowe et al., 2001 \\
\hline
\end{tabular}

*390 + 442 double mutation confers resistance to dinitroaniline herbicides.

TABLE 2 | Common $\alpha$-tubulin mutations and mutation sites shared by the protozoan Toxoplasma and higher plants.

\begin{tabular}{|c|c|c|c|c|}
\hline Site & Amino acid substitution & Tubulin Gene (Isoform) & Organism & References \\
\hline \multirow[t]{4}{*}{136} & Leu136Phe & AAA21350.1 ( $\alpha$-tubulin) & T. thermophila & Lyons-Abbott et al., 2010 \\
\hline & Leu136Phe & XP_002364807.1 (a1-tubulin) & T. gondii & Morrissette et al., 2004 \\
\hline & Leu136Phe & BAJ06363.1 (TUA1) & A. aequalis & Hashim et al., 2012 \\
\hline & Leu136Phe & CAE52515.1 ( $\alpha 2$-tubulin) & S. viridis & Délye et al., 2004 \\
\hline \multirow[t]{4}{*}{239} & Thr239lle & XP_002364807.1 (a1-tubulin) & T. gondii & Morrissette et al., 2004 \\
\hline & Thr239lle & AAC05717.1 (TUBA1) & E. indica & Yamamoto et al., 1998; Anthony and Hussey, 1999 \\
\hline & Thr239lle & MT514937 (TUA4) & L. rigidum & Fleet et al., 2017; Chen et al., 2018b \\
\hline & Thr239lle & CAE52515.1 ( $\alpha 2$-tubulin) & S. viridis & Délye et al., 2004 \\
\hline \multirow[t]{2}{*}{268} & Met268Thr & XP_002364807.1 (a1-tubulin) & T. gondii & Ma et al., 2007 \\
\hline & Met268Thr & AAC05717.1 (TUBA1) & E. indica & Yamamoto et al., 1998 \\
\hline \multirow[t]{4}{*}{243} & Arg243Cys & XP_002364807.1 ( $\alpha 1$-tubulin) & T. gondii & Morrissette et al., 2004 \\
\hline & Arg243Ser & XP_002364807.1 (a1-tubulin) & T. gondii & Morrissette et al., 2004 \\
\hline & Arg243Lys & MT514937 (TUA4) & L. rigidum & Chu et al., 2018 \\
\hline & Arg243Met & MT514937 (TUA4) & L. rigidum & Chu et al., 2018 \\
\hline
\end{tabular}

Information about plant species is in bold.

with resistance-endowing mutations occurring largely in TUA3 and TUA4, according to our sequencing results in several resistant populations (Chen et al., 2018b, 2020b; Chu et al., 2018). Moreover, the same $\alpha$-tubulin isoform from a single plant can be encoded by transcripts with differences only in untranslated regions (UTR), and thus adding another layer of complexity to tubulin gene sequencing and cloning (Chen et al., 2020b). In addition, there exists a substantial amount of synonymous mutation among $\alpha$-tubulin transcripts encoding the same isoform from different populations, which challenges the success of PCR amplification by using a single primer pair (Chen et al., 2020b). This discovery suggests care should be taken when attempting to definitively determine the presence or absence of TSR mutations if the herbicide target is derived from a multiple gene family, even in a diploid species (i.e., it is similar to herbicides that target single genes in polypoid species). Also, it is worth noting that, due to genetic variation in different populations or even individuals within a population, one cannot entirely rely on RNA-seq information collected from a small number of plants. In these cases, validation of RNA-seq data by isoform-specific PCR is critical, as errors in alignment and assembly can occur when assembling highly similar sequences from the same gene family.

Due to the redundancy of function in a multi-gene family like tubulin, a greater level of diversity in resistance mutations is possible at both the population and individual level. For instance, at least three TUA4 mutations were previously identified in L. rigidum population M4/16, including Val-202-Phe, Thr-239Ile, and Arg-243-Lys/Met (Chen et al., 2018b; Chu et al., 2018), and individuals with different combinations of mutations (e.g., $202+243,202+239$, or $239+243$ ) have also been identified (Fleet et al., 2017; Chu et al., 2018) most likely due to obligate out-crossing in Lolium. More than two resistance alleles can exist in a single plant due to presence of multiple gene copies or transcripts. For instance, a plant homozygous for the Val-202-Phe mutant alleles in TUA4 also has the Arg-390-Cys + Asp-442-Glu resistance allele in TUA3 (Chen et al., 2020b). Nevertheless, the frequency of resistance mutations varies even among individuals of a population. In one study, 39 resistant L. rigidum plants were analyzed. The 
Val-202-Phe mutation was most commonly found (90\%), with the Arg-243-Met mutation occurring in only $7 \%$ of screened plants. Furthermore, no plants were identified as homozygous for the Arg-243-Met mutation (Chen et al., 2018b; Chu et al., 2018). This is likely related to the herbicide selection pressure and fitness penalties associated with this mutant allele (see below). As more resistant populations/plants are analyzed, a clearer picture of resistance mutation frequency will be determined in L. rigidum, which may be echoed in other plant species.

Unlike TSR to other herbicides (e.g., glyphosate) involving target gene duplication/overexpression, the chance is rare for evolution of such TSR mechanisms to dinitroaniline herbicides in weeds, unless both $\alpha$ - and $\beta$-tubulin are involved. This is expected, as the amount of $\alpha$ - and $\beta$-tubulin isoforms are in dynamic balance for cell vitality, and overexpression of either of the two may be lethal (Anthony and Hussey, 1998). In addition, tubulins are structural proteins and constitutively expressed in abundance, thus overexpression is a less-likely mechanism for conferring resistance.

\section{NTSR Mechanisms to Dinitroaniline Herbicides}

No difference in herbicide uptake and/or translocation has so far been ascribed to dinitroaniline resistance (McAlister et al., 1995; Hashim et al., 2012), although dinitroaniline translocation patterns are herbicide-, weed species-, and experiment-dependent (Hawxby, 1974). This is in line with the fact that dinitroaniline herbicides are often phytotoxic to germinating seedlings and therefore little whole plant translocation of the herbicide is needed for activity. Instead, thus far, enhanced dinitroaniline metabolism (metabolic resistance) has been demonstrated as the main NTSR mechanism in studied weed species. It has been challenging to identify the major trifluralin metabolic pathway and to isolate trifluralin metabolites in plants (Probst et al., 1967; Biswas and Hamilton, 1969), and extraction and quantification of dinitroaniline metabolites is hindered by the highly volatile nature of dinitroaniline herbicides. These difficulties have meant that TSR has been the primary research focus in understanding resistance mechanisms to dinitroanilines in plants. Nevertheless, essential dinitroaniline herbicide metabolites are recently identified using yeast-expressed plant cytochrome P450 enzymes (see below) (Abdollahi et al., 2021).

There is some indirect evidence for enhanced dinitroaniline herbicide metabolism in resistant weed species. In A. myosuroides, a single population that can metabolize chlorotoluron (and that is cross-resistant to pendimethalin) is thought to be metabolically resistant due to oxidative degradation of the 4-methyl group in pendimethalin (James et al., 1995). In $L$. rigidum, the $\mathrm{P} 450$ inhibitor malathion showed a synergistic effect with pendimethalin (Tardif and Powles, 1999), and phorate [another cytochrome P450 inhibitor (Ferhatoglu et al., 2005)] can partially reverse trifluralin resistance (Busi et al., 2017). Recently, enhanced trifluralin metabolism in several L. rigidum populations has been identified and a diagnostic assay using ${ }^{14} \mathrm{C}$-trifluralin established for metabolic resistance (Chen et al., 2018a). Furthermore, a cytochrome P450 gene, CYP81A10v7, has been identified and characterized from a trifluralin resistant $L$. rigidum population. When rice seedlings were transformed with a CYP81A10v7 over-expression construct, they became moderately resistant to trifluralin (Han et al., 2020). This is the first metabolic gene identified that is clearly associated with the evolution of trifluralin resistance. It should be noted that the resistance level in the transgenic rice is lower than what was observed in the resistant L. rigidum plants. Recently, the CYP706 family from Arabidopsis and other plant species have been demonstrated to be able to metabolize most dinitroaniline herbicides (essentially to mono- and di-oxygenated compounds), including trifluralin, pendimethalin and ethalfluralin, and thus weeds have potential for the evolution of dinitroaniline metabolic resistance if these P450 genes are selected (Abdollahi et al., 2021). Taken together, these studies affirm that metabolism is a viable NTSR mechanism to dinitroanilines in weeds, though much remains to be revealed.

It is common for weeds to evolve both TSR and NTSR to commonly used herbicides and, especially in cross-pollinated species, for those mechanisms to be stacked in the same population or in the same plants. This has been previously shown for other high-use herbicides such as glyphosate, ALSor ACCase-inhibitors (Délye, 2013; Yu and Powles, 2014; Duke, 2019), and now in dinitroanilines. For instance, in a L. rigidum population (202FT), both target-site mutations and non-target-site herbicide metabolism contribute to trifluralin resistance (Chen et al., 2018a,b, 2020a,b). The prevalence of each mechanism in various populations leads us to assume that more populations containing both TSR and NTSR are to be uncovered, at least for L. rigidum.

\section{GENETIC INHERITANCE OF DINITROANILINE RESISTANCE}

Genetic inheritance studies of dinitroaniline resistance have been carried out in two self-pollinated resistant weed species: E. indica (Zeng and Baird, 1997) and S. viridis (Jasieniuk et al., 1994). In both cases, resistance was conferred by TSR, later revealed as the $\alpha$-tubulin mutations Thr-239-Ile and Met-268-Thr in E. indica (Anthony et al., 1998; Yamamoto et al., 1998), and Leu-136-Phe and Thr-239-Ile in S. viridis (Délye et al., 2004). Interestingly, and contrary to most heredity patterns of TSR, TSR to dinitroaniline herbicides in these weed species were reported to be recessive traits.

A similar inheritance study for dinitroanilines was recently carried out in one L. rigidum population (202FT) (Chen et al., 2019). Plants of this population are homozygous for the Val-202Phe mutation in TUA4. Generally, dominance of the resistance trait and gene loci contribution to herbicide resistance are ratedependent. It was shown that at $480 \mathrm{~g} \mathrm{ha}^{-1}$ trifluralin (half of the field rate), resistance is inherited as a single, recessive nuclear gene trait, similar to what has been shown in E. indica (Zeng and Baird, 1997) and S. viridis (Délye et al., 2004). However, at the lower rate of $120 \mathrm{~g}$. ha ${ }^{-1}$ trifluralin, the resistance trait does not follow a single gene, recessive pattern, indicating other 
unknown but possibly weak TSR or even metabolism-based NTSR mechanisms involved in resistance.

Given the recessive nature of TSR to dinitroaniline resistance at the field relevant rates, and dinitroanilines targeting a small nuclear gene family with multiple gene copies, it follows that dinitroaniline resistant plants should be rare. However, dinitroaniline herbicide resistance evolution in weeds should not be underestimated, especially in crosspollinating weed species with high levels of genetic diversity. Cross-pollinated species (e.g., L. rigidum) are capable of accumulating numerous resistance-conferring genes/mutations, either TSR or NTSR, in single plants quickly due to the sheer number of plants and their obligate cross-pollination. Another factor that may increase rates of dinitroaniline resistance evolution is that lower-than-field-rate levels of dinitroaniline are often encountered when environmental and soil conditions are unfavorable during or shortly after herbicide application. In these situations, minor resistance genes from the standing variations can be enriched and selected for, as has been demonstrated for resistance evolution to other pre-emergence herbicides under recurrent low herbicide rate selection (Busi and Powles, 2016).

\section{FITNESS COST OF DINITROANILINE RESISTANCE}

So far, limited fitness studies on dinitroaniline herbicide resistance have been conducted. In protists, like the haploid parasite $T$. gondii, various $\alpha$-tubulin mutations (at positions 136, 239, 243 and 268) confer dinitroaniline resistance at a cost to microtubule function ( $\mathrm{Ma}$ et al., 2008). Interestingly, when $\alpha$-tubulin mutants (Phe-52-Tyr) were grown without dinitroanilines, they spontaneously acquired a secondary mutation (Ala-273-Val or Asp-367-Val) which increased parasite fitness, although resistance level of mutants with the double mutation also decreased (Ma et al., 2007). Similarly, more secondary mutations were detected in parasites including the Phe-52-Tyr or Glu-142-Ser $\alpha$-tubulin mutations, which reduced resistance but helped improve fitness (Ma et al., 2008). It remains to be determined if the compensating tubulin mutations also occur in other species, including higher plants.

In higher plants, a fitness cost study using near-isogenic Setaria lines conducted in the greenhouse and in the field showed that, without herbicide treatment, plants homozygous for the Thr-239-Ile mutation were smaller and had lower 1,000-grain weight (Darmency et al., 2011). In L. rigidum, potential fitness cost on plant biomass was observed in plants homozygous for the Arg-243-Met mutation (Chu et al., 2018). Notably, the frequency of the Arg-243-Met mutation in the field-collected $L$. rigidum population (M4/16) was found to be low. Only two 243-Met heterozygotes were uncovered in 39 resistant plants analyzed, while homozygous resistant plants were not detected. This disequilibrium may result from a severe fitness cost of this mutation. Controlled greenhouse crosses of Arg-243-Met L. rigidum heterozygotes produced

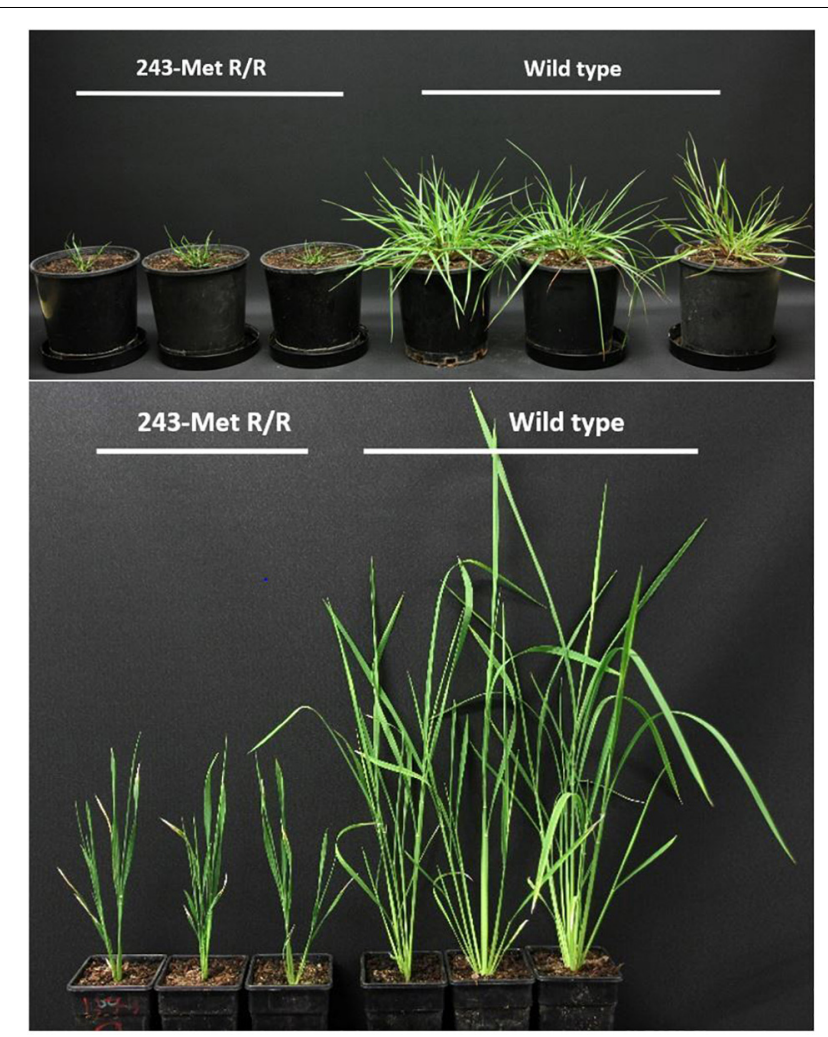

FIGURE 3 | Helical growth of Lolium rigidum (top picture, on the left) and transgenic rice (T2, bottom picture, on the left) homozygous for the $\alpha$-tubulin Arg-243-Met mutation (243-Met R/R) in comparsion to the norma growth of corresponding wild type plants (on the right). Photos were taken 42 and 30 days after $L$. rigidum and rice transplanting, respectively.

Arg-243-Met homozygotes exhibiting severe dwarfism and righthanded helical growth (Figure 3). Furthermore, homozygous rice plants transformed with the Lolium Arg-243-Met mutant tubulin gene also exhibited dwarf and helical growth (Figure 3), indicating that this Arg-243-Met $\alpha$-tubulin mutation confers aberrant plant morphology, although the cellular basis of these abnormalities remains to be investigated.

Preliminary observation of $L$. rigidum indicates a severe cost to TSR based dinitroaniline resistance in plant vegetative growth (Chu et al., 2018). In both L. rigidum and transgenic rice plants heterozygous for the 243-Met mutant allele, no altered growth phenotypes have been observed. This suggests that both the cost of resistance and the resistance itself are recessive. This is similar to the fitness cost associated with the target-site mutations (e.g., Asp-2078-Gly mutation) to ACCase-inhibiting herbicides (Menchari et al., 2008; Vila-Aiub et al., 2015) and TIPS to glyphosate (Han et al., 2017). These growth abnormalities associated with the homologous 243-Met mutant allele starkly contrast with the lack of visible growth defects shown for the most commonly identified $\alpha$-tubulin mutation, Val-202-Phe in L. rigidum, similar to the most popular ACCase resistance mutation: Ile-1781-Leu (Wang et al., 2010). This may explain the much higher frequency of the Val-202-Phe than the Arg-243-Met 


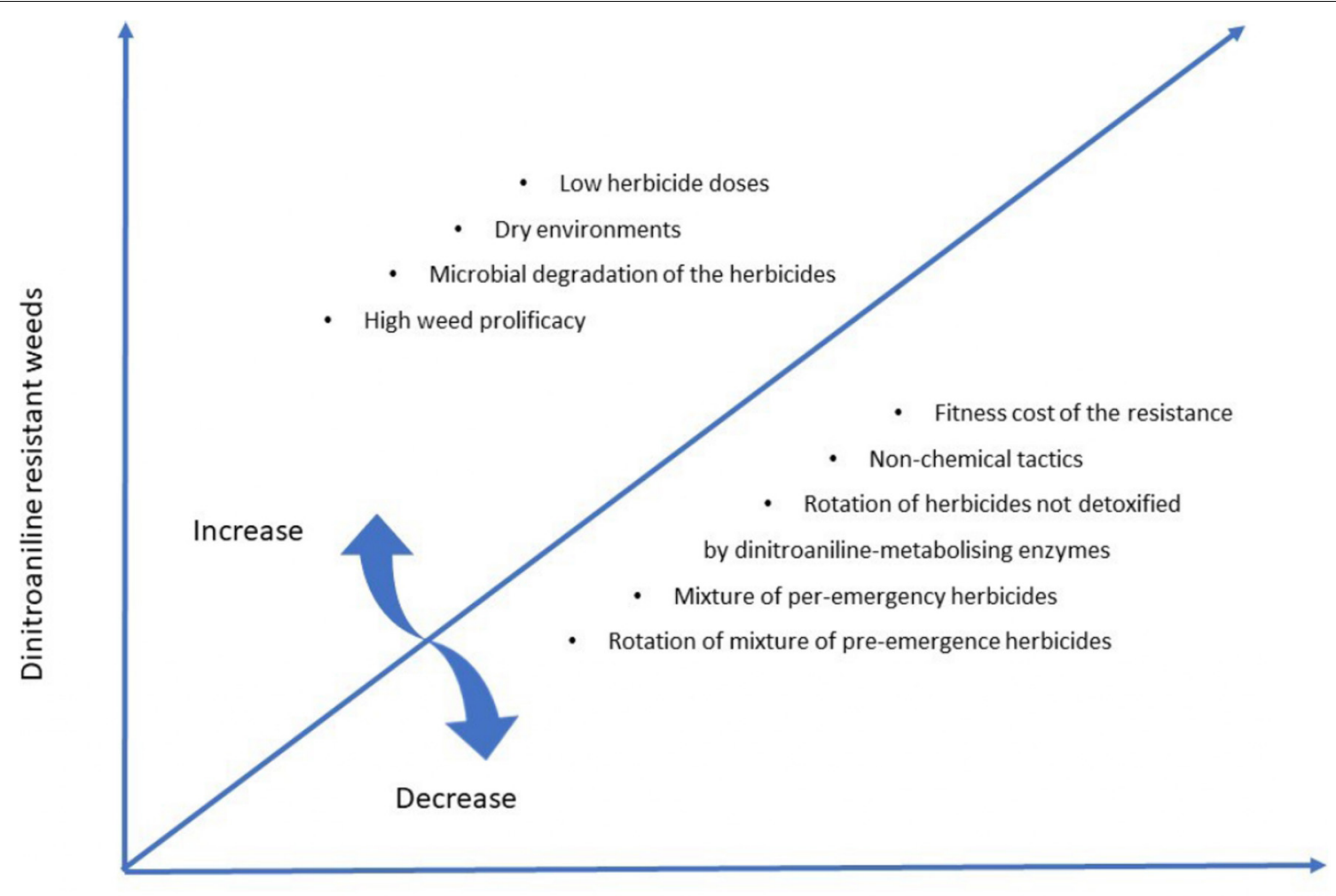

Time

FIGURE 4 | Parameters associated with dinitroaniline resistance evolution in weeds.

mutation and lack of homozygous 243-Met resistant mutant plants in the field.

\section{IMPLICATIONS FOR DINITROANILINE RESISTANCE MANAGEMENT}

In terms of resistance management, there are several implications from dinitroaniline-resistance mechanism research. First, given the recessive nature of TSR, dinitroaniline herbicides should be applied at the higher end of the labeled rates to ensure mortality of plants heterozygous for targetsite resistance mutations. Secondly, in the case of NTSR, care should be taken when mixing or rotating herbicides to minimize cross-resistance. It would be wise to rotate dinitroaniline herbicides like trifluralin with herbicides that might not be readily metabolized by dinitroanilinemetabolizing enzymes (e.g., prosulfocarb, pyroxasulfone) (Busi et al., 2017, 2020a). Computer simulation modeling, as well as the screening work with many field L. rigidum populations showed that mixtures of pre-emergency herbicides (e.g., trifluralin/prosulfocarb, trifluralin/pyroxasulfone, trifluralin/triallate) can delay the onset of resistance and mitigate the existing levels of resistance (Busi and Beckie, 2020; Busi et al., 2020b). Third, co-existence of TSR and NTSR in the same populations suggest the importance of the integrated weed management (IWM) incorporating non-chemical weed management tactics (harvest weed seed control, crop rotation, etc.) to mitigate resistance evolution, and deployment of competitive crop cultivars to suppress dinitroaniline resistant weeds, especially of mutations with concomitant fitness costs. The main message for dinitroaniline herbicide resistance evolution and management is highlighted in Figure 4.

\section{AUTHOR CONTRIBUTIONS}

All authors listed have made a substantial, direct and intellectual contribution to the work, and approved it for publication.

\section{FUNDING}

This work was supported by Scholarships for International Research Fee (SIRF) and the UWA-CSC (China Scholarship Council) to JC. AHRI is supported by the Australian Grains Research and Development Corporation and Australian Research Council (LP170100903).

\section{ACKNOWLEDGMENTS}

The authors would like to thank Jessica Strauss from AHRI for photographing Lolium and transgenic rice plants. 


\section{REFERENCES}

Abdollahi, F., Alebrahim, M. T., Ngov, C., Lallemand, E., Zheng, Y., Villette, C., et al. (2021). Innate promiscuity of the CYP706 family of P450 enzymes provides a suitable context for the evolution of dinitroaniline resistance in weed. New Phytol. 229, 3253-3268. doi: 10.1111/nph.17126

Andrews, T. S., and Morrison, I. N. (1997). The persistence of trifluralin resistance in green foxtail (Setaria viridis) populations. Weed Technol. 11, 369-372. doi: $10.1017 / \mathrm{s} 0890037 \mathrm{x} 00043086$

Anthony, R. G., and Hussey, P. J. (1998). Suppression of endogenous $\alpha$ and $\beta$ tubulin synthesis in transgenic maize calli overexpressing $\alpha$ and $\beta$ tubulins. Plant J. 16, 297-304. doi: 10.1046/j.1365-313x.1998.00296.x

Anthony, R. G., and Hussey, P. J. (1999). Double mutation in eleusine indica $\alpha$-tubulin increases the resistance of transgenic maize calli to dinitroaniline and phosphorothioamidate herbicides. Plant. J. 18, 669-674. doi: 10.1046/j.1365313x.1999.00484.x

Anthony, R. G., Waldin, T. R., Ray, J. A., Bright, S. W., and Hussey, P. J. (1998). Herbicide resistance caused by spontaneous mutation of the cytoskeletal protein tubulin. Nature 393, 260-263. doi: 10.1038/30484

Ashworth, M., Desbiolles, J., and Tola, E. (2010). Disc Seeding in Zero-Till Farming Systems: A Review of Technology and Paddock Issues. Floreat, WA: West Australian No-Tillage Farmers Association.

Barrentine, W. L., and Warren, G. F. (1971). Differential phytotoxicity of trifluralin and nitralin. Weed Sci. 19, 31-37. doi: 10.1017/s0043174500048219

Bell, A. (1998). Microtubule inhibitors as potential antimalarial agents. Parasitol. Today 14, 234-240. doi: 10.1016/s0169-4758(98)01246-0

Biswas, P. K., and Hamilton, W. Jr. (1969). Metabolism of trifluralin in peanuts and sweet potatoes. Weed Sci. 17, 206-211. doi: 10.1017/s0043174500031325

Boutsalis, P., Preston, C., and Broster, J. (2006). "Management of trifluralin resistance in annual ryegrass (Lolium rigidum Gaudin) in southern Australia," in Proceedings of the 15th Australian Weeds Conference, eds C. Preston, J. H. Watts, and N. D. Crossman (Adelaide: Weed Management Society of South Australia), 507-510.

Busi, R., and Beckie, H. J. (2020). Are herbicide mixtures unaffected by resistance? A case study with Lolium rigidum. Weed Res. doi: 10.1111/wre.12453 [Epub ahead of print].

Busi, R., Gaines, T. A., and Powles, S. (2017). Phorate can reverse P450 metabolismbased herbicide resistance in Lolium rigidum. Pest Manage. Sci. 73, 410-417. doi: $10.1002 / \mathrm{ps} .4441$

Busi, R., Goggin, D. E., Onofri, A., Boutsalis, P., Preston, C., Powles, S. B., et al. (2020a). Loss of trifluralin metabolic resistance in Lolium rigidum plants exposed to prosulfocarb recurrent selection. Pest Manage. Sci. 76, 3926-3934. doi: $10.1002 /$ ps.5993

Busi, R., Powles, S. B., Beckie, H. J., and Renton, M. (2020b). Rotations and mixtures of soil-applied herbicides delay resistance. Pest Manage. Sci. 76, 487-496. doi: 10.1002/ps.5534

Busi, R., and Powles, S. B. (2016). Cross-resistance to prosulfocarb + S-metolachlor and pyroxasulfone selected by either herbicide in Lolium rigidum. Pest Manage. Sci. 72, 1664-1672. doi: 10.1002/ps.4253

Chan, M. M., and Fong, D. (1994). Plant microtubule inhibitors against trypanosomatids. Parasitol. Today 10, 448-451. doi: 10.1016/0169-4758(94) 90182-1

Charles, W. S., and Richard, B. (1972). Phytotoxicity of Trifluralin Vapors from Soil. Weed Sci. 20, 143-146. doi: 10.1017/s0043174500035207

Chen, J., Chu, Z., Han, H., Goggin, D. E., Yu, Q., Sayer, C., et al. (2020a). A Val202-Phe $\alpha$-tubulin mutation and enhanced metabolism confer dinitroaniline resistance in a single Lolium rigidum population. Pest Manage. Sci. 76, 645-652. doi: $10.1002 /$ ps.5561

Chen, J., Chu, Z., Han, H., Patterson, E., Yu, Q., and Powles, S. (2020b). Diversity of $\alpha$-tubulin transcripts in Lolium rigidum. Pest Manage. Sci. 77, 970-977. doi: $10.1002 /$ ps.6109

Chen, J., Goggin, D. E., Han, H., Busi, R., Yu, Q., and Powles, S. (2018a). Enhanced trifluralin metabolism can confer resistance in Lolium rigidum. J. Agric. Food Chem. 66, 7589-7596. doi: 10.1021/acs.jafc.8b02283

Chen, J., Lu, H., Han, H., Yu, Q., Sayer, C., and Powles, S. (2019). Genetic inheritance of dinitroaniline resistance in an annual ryegrass population. Plant Sci. 283, 189-194. doi: 10.1016/j.plantsci.2019. 02.019
Chen, J., Yu, Q., Owen, M., Han, H., and Powles, S. (2018b). Dinitroaniline herbicide resistance in a multiple-resistant Lolium rigidum population. Pest Manage. Sci. 74, 925-932. doi: 10.1002/ps.4790

Chu, Z., Chen, J., Nyporko, A., Han, H., Yu, Q., and Powles, S. (2018). Novel $\alpha-$ tubulin mutations conferring resistance to dinitroaniline herbicides in Lolium rigidum. Front. Plant Sci. 9:97. doi: 10.3389/fpls.2018.00097

Cleary, A. L., and Hardham, A. R. (1988). Depolymerization of microtubule arrays in root tip cells by oryzalin and their recovery with modified nucleation patterns. Can. J. Bot. 66, 2353-2366. doi: 10.1139/b88-320

Congreve, M., and Cameron, J. (2014). Soil Behaviour of Pre-Emergent Herbicides in Australian Farming Systems: A Reference Manual for Agronomic Advisers. Canberra: Grains Research and Development Corporation.

Darmency, H., Picard, J., and Wang, T. (2011). Fitness costs linked to dinitroaniline resistance mutation in Setaria. Heredity 107, 80-86. doi: 10.1038/hdy.20 10.169

Dekker, J. (1999). Dinitroanilines. Available online at: http://agron-www. agron.iastate.edu/ \{\}weeds/Ag317-99/manage/herbicide/dnas.html (accessed March 14, 2021).

Délye, C. (2013). Unravelling the genetic bases of non-target-site-based resistance (NTSR) to herbicides: a major challenge for weed science in the forthcoming decade. Pest Manage. Sci. 69, 176-187. doi: 10.1002/ps.3318

Délye, C., Menchari, Y., Michel, S., and Darmency, H. (2004). Molecular bases for sensitivity to tubulin-binding herbicides in green foxtail. Plant Physiol. 136, 3920-3932. doi: 10.1104/pp.103.037432

Dempsey, E., Prudêncio, M., Fennell, B. J., Gomes-Santos, C. S., Barlow, J. W., and Bell, A. (2013). Antimitotic herbicides bind to an unidentified site on malarial parasite tubulin and block development of liver-stage Plasmodium parasites. Mol. Biochem. Parasitol. 188, 116-127. doi: 10.1016/j.molbiopara.2013.03.001

Desai, A., and Mitchison, T. J. (1997). Microtubule polymerization dynamics. Annu. Rev. Cell Dev. Biol. 13, 83-117.

Downing, K. H., and Nogales, E. (1998b). Tubulin structure: insights into microtubule properties and functions. Curr. Opin. Struct. Biol. 8, 785-791. doi: 10.1016/s0959-440x(98)80099-7

Downing, K. H., and Nogales, E. (1998a). Tubulin and microtubule structure. Curr. Opin. Cell Biol. 10, 16-22.

Duke, S. O. (2012). Why have no new herbicide modes of action appeared in recent years? Pest Manage. Sci. 68, 505-512. doi: 10.1002/ps.2333

Duke, S. O. (2019). Enhanced metabolic degradation: The last evolved glyphosate resistance mechanism of weeds? Plant Physiol. 181, 1401-1403. doi: 10.1104/ pp.19.01245

Environmental Protection Agency (EPA) (1996). Reregistration Eligibility Decision (RED) Trifluralin. Available online at: https://www3.epa.gov/pesticides/chem search/reg_actions/reregistration/red_PC-036101_1-Apr-96.pdf (accessed February 11, 2021).

Environmental Protection Agency (EPA) (2021). Pesticides Industry. Sales and Usage 2008-2012 Market Estimates. Available online at: https://www.epa.gov/sites/production/files/2017-01/documents/pesticidesindustry-sales-usage-2016_0.pdf (accessed February 11, 2021).

Epp, J. B., Schmitzer, P. R., and Crouse, G. D. (2017). Fifty years of herbicide research: Comparing the discovery of trifluralin and halauxifen-methyl. Pest Manage. Sci. 74, 9-16. doi: 10.1002/ps.4657

Ferhatoglu, Y., Avdiushko, S., and Barrett, M. (2005). The basis for the safening of clomazone by phorate insecticide in cotton and inhibitors of cytochrome P450s. Pestic. Biochem. Physiol. 81, 59-70. doi: 10.1016/j.pestbp.2004.09.002

Fleet, B., Malone, J., Preston, C., and Gill, G. (2017). Target-site point mutation conferring resistance to trifluralin in rigid ryegrass (Lolium rigidum). Weed Sci. 66, 246-253. doi: 10.1017/wsc.2017.67

Gossett, B. J., Murdock, E. C., and Toler, J. E. (1992). Resistance of Palmer amaranth (Amaranthus palmeri) to the dinitroaniline herbicides. Weed Technol. 6, 587591. doi: 10.1017/s0890037x00035843

Grover, R., Wolt, J. D., Cessna, A. J., and Schiefer, H. B. (1997). Environmental fate of trifluralin. Rev. Environ. Contam. Toxicol. 153, 1-64. doi: 10.1007/9781-4612-2302-3_1

Han, H., Vila-Aiub, M. M., Jalaludin, A., Yu, Q., and Powles, S. B. (2017). A double EPSPS gene mutation endowing glyphosate resistance shows a remarkably high resistance cost. Plant Cell Environ. 40, 3031-3042. doi: 10.1111/pce.13067

Han, H., Yu, Q., Beffa, R., González, S., Maiwald, F., Wang, J., et al. (2020). Cytochrome P450 CYP81A10v7 in Lolium rigidum confers metabolic resistance 
to herbicides across at least five modes of action. Plant J. 105, 79-92. doi: $10.1111 /$ tpj. 15040

Hashim, S., Jan, A., Sunohara, Y., Hachinohe, M., Ohdan, H., and Matsumoto, H. (2012). Mutation of alpha-tubulin genes in trifluralin-resistant water foxtail (Alopecurus aequalis). Pest Manage. Sci. 68, 422-429. doi: 10.1002/ps.2284

Hawxby, K. W. (1974). Absorption and Translocation of Dinitramine and Profluralin in Susceptible and Resistant Plants at Various Temperatures. Ph.D. thesis, Oklahoma State University, Stillwater, OK.

Heap, I. (2021). The International Herbicide-Resistant Weed Database. Available online at: www.weedscience.org (accessed March 14, 2021)

Helling, C. S. (1971). Pesticide mobility in soils III. Influence of soil properties. Soil Sci. Soc. Am. J. 35, 743-748. doi: 10.2136/sssaj1971.03615995003500050032x

Helling, C. S. (1976). Dinitroaniline herbicides in soils. J. Environ. Qual. 5, 1-15. doi: $10.2134 /$ jeq1976.00472425000500010001x

Hilton, J. L., and Christiansen, M. N. (1972). Lipid contribution to selective action of trifluralin. Weed Sci. 20, 290-294. doi: 10.1017/s0043174500035670

Hugdahl, J. D., and Morejohn, L. C. (1993). Rapid and reversible high-affinity binding of the dinitroaniline herbicide oryzalin to tubulin from Zea mays $\mathrm{L}$. Plant Physiol. 102, 725-740. doi: 10.1104/pp.102.3.725

Instituto Brasileiro do Meio Ambiente e dos Recursos Naturais Renováveis (IBAMA) (2020). Relatórios de Comercialização de Agrotóxicos. Available online at: http://www.ibama.gov.br/agrotoxicos/relatorios-decomercializacao-de-agrotoxicos\#sobreosrelatorios (accessed February 11, 2021).

Isgrigg, J. III, Yelverton, F. H., Brownie, C., and Warren, L. S. Jr. (2002). Dinitroaniline resistant annual bluegrass in North Carolina. Weed Sci. 50, 86-90. doi: 10.1614/0043-1745(2002)050[0086:drabin]2.0.co;2

James, E. H., Kemp, M. S., and Moss, S. R. (1995). Phytotoxicity of trifluoromethyland methyl-substituted dinitroaniline herbicides on resistant and susceptible populations of black-grass (Alopecurus myosuroides). Pestic. Sci. 43, 273-277. doi: $10.1002 /$ ps.2780430405

James, S. W., Silflow, C. D., Stroom, P., and Lefebvre, P. A. (1993). A mutation in the alpha 1-tubulin gene of Chlamydomonas reinhardtii confers resistance to anti-microtubule herbicides. J. Cell Sci. 106, 209-218.

Jasieniuk, M., Brûlé-Babel, A. L., and Morrison, I. N. (1994). Inheritance of trifluralin resistance in green foxtail (Setaria viridis). Weed Sci. 42, 123-127. doi: 10.1017/s0043174500084277

Jolley, A. V., and Johnstone, P. K. (1994). Degradation of trifluralin in three Victorian soils under field and laboratory conditions. Aust. J. Exp. Agric. 34, 57-65. doi: 10.1071/ea9940057

Kopczak, S. D., Haas, N. A., Hussey, P. J., Silflow, C. D., and Snustad, D. P. (1992). The small genome of Arabidopsis contains at least six expressed a-tubulin genes. Plant Cell 4, 539-547. doi: 10.2307/3869553

Lignowski, E. M., and Scott, E. G. (1971). Trifluralin and root growth. Plant Cell Physiol. 12, 701-708.

Lima, P. L. T., de Souza Magalhães, C. A., de Carvalho, R. F., Lima, L. A., de Lima, J. M., and de Bastos Andrade, L. A. (2018). Trifluralin leaching in soils cultivated with sugarcane irrigated by sub-surface drip system. IRRIGA 17:39. doi: 10.15809/irriga.2012v17n1p39

Little, M., and Seehaus, T. (1988). Comparative analysis of tubulin sequences. Comp. Biochem. Physiol. B 90, 655-670. doi: 10.1016/0305-0491(88)90320-3

Lowe, D. B., Swire-Clark, G. A., McCarty, L. B., Whitwell, T., and Baird, W. V. (2001). Biology and molecular analysis of dinitroaniline-resistant Poa annua L. Int. Turfgrass Soc. Res. J. 9, 1019-1025.

Lyons-Abbott, S., Sackett, D. L., Wloga, D., Gaertig, J., Morgan, R. E., Werbovetz, K. A., et al. (2010). $\alpha$-Tubulin mutations alter oryzalin affinity and microtubule assembly properties to confer dinitroaniline resistance. Eukaryot. Cell 9, 18251834. doi: $10.1128 /$ ec.00140-10

Ma, C., Li, C., Ganesan, L., Oak, J., Tsai, S., Sept, D., et al. (2007). Mutations in $\alpha$ tubulin confer dinitroaniline resistance at a cost to microtubule function. Mol. Biol. Cell 18, 4711-4720. doi: 10.1091/mbc.e07-04-0379

Ma, C., Tran, J., Li, C., Ganesan, L., Wood, D., and Morrissette, N. (2008). Secondary mutations correct fitness defects in Toxoplasma gondii with dinitroaniline resistance mutations. Genetics 180, 845-856. doi: 10.1534/ genetics.108.092494

McAlister, F. M., Holtum, J. A., and Powles, S. B. (1995). Dintroaniline herbicide resistance in rigid ryegrass (Lolium rigidum). Weed Sci. 43, 55-62. doi: 10.1017/ s0043174500080826
Menchari, Y., Chauvel, B., Darmency, H., and Délye, C. (2008). Fitness costs associated with three mutant acetyl-coenzyme A carboxylase alleles endowing herbicide resistance in black-grass Alopecurus myosuroides. J. Appl. Ecol. 45, 939-947. doi: 10.1111/j.1365-2664.2008.01462.x

Morejohn, L. C., Bureau, T. E., Mole-Bajer, J., Bajer, A. S., and Fosket, D. E. (1987). Oryzalin, a dinitroaniline herbicide, binds to plant tubulin and inhibits microtubule polymerization in vitro. Planta 172, 252-264. doi: 10.1007/ bf00394595

Morrison, I. N., Todd, B. G., and Nawolsky, K. M. (1989). Confirmation of trifluralin-resistant green foxtail (Setaria viridis) in Manitoba. Weed Technol. 3, 544-551. doi: 10.1017/s0890037x00032796

Morrissette, N. S., Mitra, A., Sept, D., and Sibley, L. D. (2004). Dinitroanilines bind $\alpha$-tubulin to disrupt microtubules. Mol. Biol. Cell 15, 1960-1968. doi: 10.1091/mbc.e03-07-0530

Mudge, L. C., Gossett, B. J., and Murphy, T. R. (1984). Resistance of goosegrass (Eleusine indica) to dinitroaniline herbicides. Weed Sci. 32, 591-594. doi: $10.1017 / \mathrm{s} 0043174500059610$

Oerke, E. C. (2006). Crop losses to pests. J. Agric. Sci. 144, 31-43. doi: 10.1017/ s0021859605005708

Owen, M. J., Martinez, N. J., and Powles, S. B. (2014). Multiple herbicide-resistant Lolium rigidum (annual ryegrass) now dominates across the Western Australian grain belt. Weed Res. 54, 314-324. doi: 10.1111/wre.12068

Owen, M. J., Walsh, M. J., Llewellyn, R. S., and Powles, S. B. (2007). Widespread occurrence of multiple herbicide resistance in Western Australian annual ryegrass (Lolium rigidum) populations. Crop Pasture Sci. 58, 711-718. doi: $10.1071 / \operatorname{ar} 06283$

Parka, S. J., and Soper, O. F. (1977). The physiology and mode of action of the dinitroaniline herbicides. Weed Sci. 79-87. doi: 10.1017/s0043174500032975

Pham, C. L., and Morrissette, N. S. (2019). The tubulin mutation database: A resource for the cytoskeleton community. Cytoskeleton 76, 186-191. doi: 10. $1002 / \mathrm{cm} .21514$

Powles, S. B., and Yu, Q. (2010). Evolution in Action: Plants Resistant to Herbicides. Annu. Rev. Plant Biol. 61, 317-347. doi: 10.1146/annurev-arplant042809-112119

Probst, G. W., Herberg, R. J., Herberg, R. J., Holzer, F. J., Parka, S. J., Van der Schans, C., et al. (1967). Fate of trifluralin in soils and plants. J. Agric. Food Chem. 15, 592-599. doi: 10.1021/jf60152a016

Qin, X., Gianì, S., and Breviario, D. (1997). Molecular cloning of three rice $\alpha$-tubulin isotypes: differential expression in tissues and during flower development. Biochim. Biophys. Acta 1354, 19-23. doi: 10.1016/s0167-4781(97) 00110-3

Ryan, G. (1970). Resistance of common groundsel to simazine and atrazine. Weed Sci. 614-616. doi: 10.1017/s0043174500034330

Savage, K. E., and Barrentine, W. L. (1969). Trifluralin persistence as affected by depth of soil incorporation. Weed Sci. 17, 349-352. doi: 10.1017/ s0043174500054205

Shaner, D. L. (2014). Lessons learned from the history of herbicide resistance. Weed Sci. 62, 427-431. doi: 10.1614/ws-d-13-00109.1

Shaw, S. L., and Vineyard, L. (2014). "Cortical microtubule array organization and plant cell morphogenesis," in Plant Cell Wall Patterning and Cell Shape, ed. H. Fukuda (Hoboken, NJ: Wiley), 97-126. doi: 10.1002/9781118647 363.ch4

Snustad, D. P., Haas, N. A., Kopczak, S. D., and Silflow, C. D. (1992). The small genome of Arabidopsis contains at least nine expressed $\beta$-Tubulin genes. Plant Cell 4, 549-556. doi: 10.2307/3869554

Soltani, N., Shropshire, C., and Sikkema, P. H. (2020). Efficacy of trifluralin compared to ethalfluralin applied alone and co-applied with halosulfuron for weed management in white bean. Agric. Sci. 11, 837-848. doi: 10.4236/as.2020. 119053

Spencer, W. F., and Cliath, M. M. (1974). Factors affecting vapor loss of trifluralin from soil. J. Agric. Food Chem. 22, 987-991. doi: 10.1021/jf6019 $6 \mathrm{a} 038$

Stephenson, G. R., Solomon, K. R., Frank, R., Hsiung, T., and Thompson, D. G. (2001). Pesticides in the Environment. Section 3. (Guelph, ON: University of Guelph), 1-12.

Stokkermans, T. J. W., Schwartzman, J. D., Keenan, K., Morrissette, N. S., Tilney, L. G., and Roos, D. S. (1996). Inhibition of Toxoplasma gondii replication by dinitroaniline herbicides. Exp. Parasitol. 84, 355-370. 
Strachan, S. D., and Hess, F. D. (1983). The biochemical mechanism of action of the dinitroaniline herbicide oryzalin. Pestic. Biochem. Physiol. 20, 141-150. doi: 10.1016/0048-3575(83)90018-4

Strang, R. H., and Rogers, R. L. (1971). A microradioautographic study of 14CTrifluralin absorption. Weed Sci. 19, 363-369. doi: 10.1017/s004317450004 9158

Tardif, F. J., and Powles, S. B. (1999). Effect of malathion on resistance to soilapplied herbicides in a population of rigid ryegrass (Lolium rigidum). Weed Sci. 47, 258-261. doi: 10.1017/s0043174500091748

Tilney, L. G., Bryan, J., Bush, D. J., Fujiwara, K., Mooseker, M. S., Murphy, D. B., et al. (1973). Microtubules: evidence for 13 protofilaments. J. Cell Biol. 59, 267-275. doi: $10.1083 /$ jcb.59.2.267

Timmons, F. L. (2005). A history of weed control in the United States and Canada. Weed Sci. 53, 748-761. doi: 10.1614/0043-1745(2005)053[0748:ahowci]2.0.co;2

Vaughan, M. A., and Vaughn, K. C. (1988). Carrot microtubules are dinitroaniline resistant. I. Cytological and cross-resistance studies. Weed Res. 28, 73-83. doi: 10.1111/j.1365-3180.1988.tb00789.x

Vaughn, K. C. (1986). Cytological studies of dinitroaniline-resistant Eleusine. Pestic. Biochem. Physiol. 26, 66-74. doi: 10.1016/0048-3575(86)90063-5

Vaughn, K. C., Vaughan, M. A., and Gossett, B. J. (1990). A biotype of goosegrass (Eleusine indica) with an intermediate level of dinitroaniline herbicide resistance. Weed Technol. 4, 157-162. doi: 10.1017/s0890037x00025161

Vila-Aiub, M. M., Gundel, P. E., and Preston, C. (2015). Experimental methods for estimation of plant fitness costs associated with herbicide-resistance genes. Weed Sci. 63, 203-216. doi: 10.1614/ws-d-14-00062.1

Waldin, T. R., Ellis, J. R., and Hussey, P. J. (1992). Tubulin-isotype analysis of two grass species-resistant to dinitroaniline herbicides. Planta 188, 258-264. doi: $10.1007 /$ bf00216822

Wang, T., Picard, J., Tian, X., and Darmency, H. (2010). A herbicide-resistant ACCase 1781 Setaria mutant shows higher fitness than wild type. Heredity 105 , 394-400. doi: 10.1038/hdy.2009.183
Wright, W. L., and Warren, G. F. (1965). Photochemical decomposition of trifluralin. Weeds 13, 329-331. doi: 10.2307/4040887

Yamamoto, E., and Baird, W. V. (1999). Molecular characterization of four $\beta$ tubulin genes from dinitroaniline susceptible and resistant biotypes of Eleusine indica. Plant Mol. Biol. 39, 45-61.

Yamamoto, E., Zeng, L., and Baird, W. V. (1998). $\alpha$-Tubulin missense mutations correlate with antimicrotubule drug resistance in Eleusine indica. Plant Cell 10, 297-308. doi: 10.2307/3870706

Yoshikawa, M., Yang, G., Kawaguchi, K., and Komatsu, S. (2003). Expression analyses of $\beta$-tubulin isotype genes in rice. Plant Cell Physiol. 44, 1202-1207. doi: $10.1093 / \mathrm{pcp} / \mathrm{pcg} 150$

Yu, Q., and Powles, S. (2014). Metabolism-based herbicide resistance and crossresistance in crop weeds: a threat to herbicide sustainability and global crop production. Plant Physiol. 166, 1106-1118. doi: 10.1104/pp.114.24 2750

Zeng, L., and Baird, W. (1997). Genetic basis of dinitroaniline herbicide resistance in a highly resistant biotype of goosegrass (Eleusine indica). J. Hered. 88, 427-432. doi: 10.1093/oxfordjournals.jhered.a023130

Conflict of Interest: CS is employed by the company Nufarm Limited.

The remaining authors declare that the research was conducted in the absence of any commercial or financial relationships that could be construed as a potential conflict of interest.

Copyright (c) 2021 Chen, Yu, Patterson, Sayer and Powles. This is an open-access article distributed under the terms of the Creative Commons Attribution License (CC BY). The use, distribution or reproduction in other forums is permitted, provided the original author(s) and the copyright owner(s) are credited and that the original publication in this journal is cited, in accordance with accepted academic practice. No use, distribution or reproduction is permitted which does not comply with these terms. 